INDEPENDENT JOURNAL OF MANAGEMENT \& PRODUCTION (IJM\&P)

\title{
EMOTIONAL INTELLIGENCE AND SUCCESSFUL CHANGE MANAGEMENT IN THE NIGERIAN BANKING INDUSTRY
}

\author{
John N. N. Ugoani \\ College of Management and Social Sciences, Rhema University, \\ Nigeria \\ E-mail: drjohnugoani@yahoo.com
}

Submission: 04/10/2016

Accept: 23/10/2016

\section{ABSTRACT}

Successful organizational change requires a supportive culture and competence development driven by exceptional leadership that can influence business strategy in allocating financial, human and material resources, processes and systems that focus on collaborative imperatives. Change management is the lubricant that oils the wheels of organizations in the race for competitive advantage. Many organizational change efforts face resistance mainly because of the method of implementation. Change Management involves the ability to communicate, influence, collaborate and work in harmony with colleagues. Emotional intelligence competencies allow organizational members to acknowledge the need for change, remove barriers, and enlist others in pursuit of new initiatives aimed at organizational success. Beginning in the late 1990s, banks in Nigeria embarked on change management through BPR that involved emotional intelligence competencies which saw the banking industry's shareholders' funds rising from minus N792m in 1996 to N1,935bn in 2011. The survey research design was used for the study, and data were analyzed to demonstrate the relationship between emotional intelligence and successful change management. It was found that El has strong positive relationship with successful change management in the Nigerian banking industry. 
INDEPENDENT JOURNAL OF MANAGEMENT \& PRODUCTION (IJM\&P)

http://www.ijmp.jor.br

v. 8, n. 2, April - June 2017

ISSN: 2236-269X

DOI: 10.14807/ijmp.v8i2.550

Keywords: Leadership, Change catalyst, Business process reengineering, Emotional competencies, Successful change management

\section{INTRODUCTION}

An organization is an open system and it depends on the environment in which it operates for growth and survival. For example, for a bank to achieve its objectives, it will be affected by the economy, labour, technology, culture, competition, laws, including international factors that put banks around the world in a state of continuous change. Between 1986 and 1996, the Nigerian banking industry experienced more changes than it did in the first 90 years of banking in the country.

According to Muo (1999) the changes were complex and they were continuous. He posits that the structural changes were interrelated with the Structural Adjustment Programme (SAP) introduced by the Babangida administration in 1986.

SAP was anchored on the enthronement of market forces, export promotion and self-reliance, public sector efficiency, and increased private sector participation, realistic exchange rate and cost consciousness, all to be achieved through deregulation, privatization, commercialization, liberalization, and subsidy removal. This brought about the liberalization of bank licensing, leading to almost 300 percent increase in the number of banks within five years.

The banking boom soon gave way to banking doom. Consequently, distress crept into the Nigerian banking industry. By 1999, many banks failed, some were distressed and others taken over by the regulatory authorities. The scenario made change in the Nigerian banking industry more urgent than ever before. As at 1996, 47 out of the 115 banks in Nigeria were distressed, while 3 were potentially distressed.

The liquidity ratios of banks were 0.49 percent against the prescribed prudential minimum of 30 percent in 1996. The liquidity ratio of the distressed banks was minus 120 percent, indicating that depositors funds of N38,061,592, were in jeopardy. In the same period, adjusted shareholders' funds decreased from negative N8,791.1m in 1995 to negative N791.2m in 1996 (NDIC, 1996).

By this time, the Nigerian banking industry was not short of leaders, but possibly short of core banking professionals and change catalysts, whose leadership 
INDEPENDENT JOURNAL OF MANAGEMENT \& PRODUCTION (IJM\&P)

http://www.ijmp.jor.br

v. 8, n. 2, April - June 2017

ISSN: 2236-269X

DOI: 10.14807/ijmp.v8i2.550

role was necessary for bank profitability. Leadership plays key roles in organizational change process because it is linked to efficiency, to creating a vision of what the organization wants to be, galvanizing support and getting people to share the vision and enthusiasm, initiatives and mission (MORRELL et al., 2004; MUO, 1999; AGBATO, 1990).

According to Olasinde (2016) the banking industry is the oil that greases the wealth of the economy, by providing financial resources needed for the production of goods and services. And for it to play its role successfully there must be core professionals in the industry and other financial institutions because they are all in the process of financial intermediation.

Change catalyst, leadership, empathy are among emotional intelligence factors recognized to have profound positive relationship with successful organizational change management. Salovey and Mayer (1990) describe the term emotional intelligence (EI) as the ability to perceive and express emotions, assimilate emotions in thought, understand and reason with emotions, and regulate emotions in the self and others.

In another proposal, Goleman (1995) suggests that emotional intelligence involves four key competencies of self awareness, self-management, socialawareness and relationship management; and that these together with other competencies are critical for workplace excellence. Goleman (1995) hypothesizes that emotional intelligence can be as "powerful and at times more powerful", than intelligence quotient, (IQ) in predicting success at a variety of life tasks.

The term emotional quotient (EQ) first coined by Bar-On (1997) as a counterpart to IQ was concerned with cognitive ability. He thought of EQ as representative of a set of social and emotional skills and abilities that help individuals to cope with the demands of daily life. On the other hand, Goleman (1998) sees emotional intelligence as a bundle of skills and competencies that distinguish star performers from average ones in the work arena.

He makes a distinction between emotional intelligence and emotional competence. According to him, emotional intelligence provides the bedrock for the development of a large number of competencies that help people perform more effectively. Different instruments have been used by the major contributors to the 
INDEPENDENT JOURNAL OF MANAGEMENT \& PRODUCTION (IJM\&P)

http://www.ijmp.jor.br

v. 8, n. 2, April - June 2017

ISSN: 2236-269X

DOI: 10.14807/ijmp.v8i2.550

emotional intelligence theory to compare the effect of emotional intelligence and intelligent quotient to work excellence.

For example, early studies of the correlation between IQ and El show a range from 0 to .36. Goleman (1998) insists that IQ will be more "powerful predictor" than El in terms of career choice because it sorts people out before they embark on a career, determining which fields or profession they enter, but within a job or profession, and to know which individuals rise to the top and which plateau or fail, El provides the greatest influence.

For example, in Boyatzis's (1982) classic study of more than two thousand supervisors, middle-managers, and executives at twelve organizations, all but two of the sixteen competencies; such as: emotional self-awareness, accurate selfassessment, self-confidence, self-control, visionary leadership; among others; that distinguish between high and low performers were emotional intelligence competencies.

This work validates Goleman's (1995) view, suggesting also that an underlying emotional intelligence ability is necessary to changing value systems, as well as rapid technological advancement through the information super-high way. Those who will contribute to organizational excellence are individuals who are change agents, adaptable, flexible, creative, resilient, self-reliant, service-oriented, sensitive, optimistic, compassionate, team champions, and self-motivated. Relationship management is key to organizational change.

Ability to collaborate with bosses, peers, subordinates and the environment is an important competence for organizational change. Goleman and Cherniss (2001) did a sample study of 515 managers from Japan, Germany, and Latin America, and discovered that El alone accounted for 74 percent of performance success, and 24 percent for failure in organizational performance. Change is an inherent aspect of human existence.

Great social and technological feasts have been achieved all through history as a result of innovative efforts driven by the constant desire for something better. Technological discoveries and inventions such as the wheal, electricity, penicillin, telephones, the internal combustion engine, radio, and television broadcasting, 
INDEPENDENT JOURNAL OF MANAGEMENT \& PRODUCTION (IJM\&P)

http://www.ijmp.jor.br

v. 8, n. 2, April - June 2017

ISSN: 2236-269X

DOI: 10.14807/ijmp.v8i2.550

aeroplanes, the computer, the internet, etc are all products of innovation, which have had a fundamental impact on human existence.

Also, concepts such as democracy, the rule of law, human rights, limited liability companies, etc are the products of important economic changes that visionary leaders brought about that have created permanent change. Guest (1964) believes that successful leadership is critical to organizational change. Among the major objectives of innovation is to bring about change by fostering an organizational culture that enables harnessing innovative efforts within the organization in such a manner that ensures that they deliver the expected results.

Change sometimes refers to external changes in technology, customers, competitions, market structures, or the social and political environments. Change also refers to internal changes involving how an organization adapts to changes in the environments. The concern is whether these internal changes in practices, views and strategies will match the external changes, and frequently, it is the concerns over the quantum and pace of internal changes that lead organizations to embark on change programmes.

Exceptional product quality and change takes a supportive organizational culture, competence development and focused action to happen. It is driven by leadership, a collaborative environment, a continuous learning process that allows people to experiment with new ideas.

Emotionally intelligent organizations are able to leverage the talent of their members to meet challenges more effectively because it is easier to create virtual teams when team members are able to focus on solving problems, creating new ideas, serving customers and adapting to change management in the work environment.

Organizations are concerned about change because it is capable of creating opportunities and threats. The consequences of change may present viable business opportunities. According to Akanwa and Agu (2005) change can also render current business practices, products or services obsolete and consequently increase business and risks.

The phenomenon of change is seen as a common feature of business organizations and new ideas are considered strategic in responding to major 
INDEPENDENT JOURNAL OF MANAGEMENT \& PRODUCTION (IJM\&P)

http://www.ijmp.jor.br

v. 8, n. 2, April - June 2017

ISSN: 2236-269X

DOI: 10.14807/ijmp.v8i2.550

changes. They posit that the presence of new skill or lack of it makes a major difference in the management process. In the business world, change in tastes and preferences of customers is common. The trends and choices of today easily become obsolete and outdated.

The phenomenon of change itself and its dynamism are complex and cannot be fully estimated. Globalization has integrated Nigeria into the one large world economy, and many organizations are changing so as to a have a competitive edge. Among the organizations in the forefront of the change process is the banking industry.

The banking industry in Nigeria is credited with successful reengineering efforts to meet the needs of customers in the $21^{\text {st }}$ century banking environment. Among the processes reengineered in the banking sector include credit transfers, withdrawal and deposit operations, credit appraisal and interbank operations. Business Process Reengineering (BPR) project in the banking industry has greatly facilitated expansion in their information and communication technology (ICT) capacity through on-line computerization.

This change process has given rise to the current banking buzzwords as online real-time system, networking, electronic cash transfers, internet banking, among others. Compared to what was obtainable in the 1990s, it is important to state that BPR and the corresponding human skills, capabilities and competencies have revolutionized the banking sector in Nigeria with radical improvements in customer service delivery, overall profitability, size of customer deposits, loan asset quality, costs and capital base.

According to Hammer (1990) BPR is a fundamental rethinking and radical redesigning of business processes to bring about dramatic changes in performance. It is a radical breakaway from the outdated rules, traditions and foundations underlying business operations. (HAMMER; CHAMPY, 1993; HAMMER; STATON, 1995; POVEY 1996; GOLEMAN, et al, 2000).

Change enhances productivity or the productive potential of economic, human and material resources. In recent history, great attention has been paid to change management in the Nigerian banking industry, because of the distress experience in the industry in the late 1980s through 2010. 


\subsection{Statement of the problem}

Since the advent of banking in Nigeria over 120 years ago, the industry has been battling with the issues of bank failures and currently with how to manage change so as to remain competitive and productive in a constantly changing global environment.

Service productivity is more problematic than manufacturing productivity, and in many situations more difficult to measure and hard to manage because it involves intellectual activities and a high degree of variability because service provision particularly in the banking industry has become largely important in the economy. Nigerian banks beginning from the late 1990s and the early 2000s ventured into strategic changes including computerization of operations, through BPR.

This was based on the theory that much productivity gains in the developed world have come from technological improvements. There is also the commonly held view that knowledge workers are the main determinants of productivity. According to that approach, the route to productivity gains involves getting employees to think and work better. Most of the banks that engaged in BPR started to lay off employees as a change management process. But this posed more challenges in terms of turnover and its adverse effects on productivity.

According to Bogue, et al (1999) chief executive officers (CEOs) in unsuccessful reengineering applications where those more involved in reductions of managers and employees and less engaged in activities surrounding business changes (BARLETT; GHOSHAL, 1995), Layoffs often affect productivity, the effect can be positive and negative. Initially, productivity may increase after layoffs, the workload remains the same but fewer workers do the work.

However as time goes by, the remaining workers may experience an increased risk of 'burnout' and they may fear additional job cuts and the most capable workers may decide to leave (MARGRETTA, 1998; ROACH, 1998; STALK, et al, 1992).

Obviously the unsuccessful CEOs might have been oblivious of the caution. Today, banks in Nigeria still have the challenges of high cost of doing business, characterized by high administrative and contract costs, poor service delivery, with 
DOI: 10.14807/ijmp.v8i2.550

malfunctioning automatic teller machines (ATMs). These suggest that the challenges in the banking industry include how to manage change for competitive advantage in the years ahead. (DAVENPORT, 1993; HAMMER, 1996; 1993; 1999; ROHLEDER; SILVER, 1997; OVIA, 2003; DRUCKER, 1998; 1999; ROACH, 1998)

\subsection{Objective of the study}

The study was designed to evaluate the relationship of emotional intelligence and change management in the Nigerian banking industry.

\subsection{Delimitation}

The study was delimited to banks in Nigeria.

\subsection{Significance of the study}

The study will be useful to students, banks, the regulatory authorities, academics and the general public interested in the areas of emotional intelligence change management in the banking industry.

\subsection{Limitations of the study}

The study was limited by lack of research grant, distance within Nigeria because of its vast nature, and lack of relevant literature in the areas of interest. However, these constraints did not affect the quality of the study.

\subsection{Hypotheses}

To guide the study, the following hypotheses were formulated and tested at 0.01 level of significance.

Ho: Emotional intelligence is not powerful in successful change management in the Nigerian industry banking.

Ho: Emotional intelligence is powerful in successful change management in the Nigerian industry banking.

\section{LITERATURE REVIEW}

Organizations embark on change management to improve service quality and maintain competitive advantage. In many organizations, the generation of ideas is not the problem, but the leadership to communicate such ideas in such ways that 
INDEPENDENT JOURNAL OF MANAGEMENT \& PRODUCTION (IJM\&P)

http://www.ijmp.jor.br

v. 8, n. 2, April - June 2017

ISSN: 2236-269X

DOI: 10.14807/ijmp.v8i2.550

would lead to successful change. Often, people do not resist change management, but what they do resist is the method of the change process.

This places high responsibility on leadership. Leadership and the role of leaders are important in any change management process. According to Omiyi (2008) great leaders are mindful of limiting factors and they put in place actions to address them. Successful change leaders spend about 80 to 90 percent of their time anticipating and addressing possible limiting factors.

To achieve a successful change in organizations, the importance of communication with key stakeholders is very necessary. Most of the critical competencies needed for successful change management in organizations are embedded in Goleman's (2001) emotional intelligence competencies.

The organization of the competencies under the various constructs is not random, they appear in synergistic clusters that support and facilitate each other to bring about successful change in organizations. According to Goleman (2001) an emotional competence is a learned capability based on emotional intelligence that results in outstanding work performance. It shows how much of El that is translated into the change management process (COOPER, 1997).

\subsection{Emotional Intelligence Clusters}

Emotional Intelligence competencies seem to operate most effectively in synergistic groupings, with the evidence suggesting that mastery of a critical mass or cluster of competencies is a necessary preclude arousing the competencies in the other clusters, but when both are demonstrated, the person is typically more effective in professional and management positions (GOLEMAN, 2001).

The first cluster of emotional competencies within the personal competences domain is Self-Awareness. Self-Awareness is characterized by a deep understanding of one's emotions, strengths, and weaknesses, and the ability to accurately and honestly self-assess.

Fundamental concepts of Self-Awareness include individuals' personality traits, personal values, emotions, habits and the psychological needs that drive behaviours. Three competencies lie within the Self-Awareness cluster: emotional self-awareness, self-assessment, and self-confidence. 
INDEPENDENT JOURNAL OF MANAGEMENT \& PRODUCTION (IJM\&P)

http://www.ijmp.jor.br

v. 8, n. 2, April - June 2017

ISSN: 2236-269X

DOI: 10.14807/ijmp.v8i2.550

Emotional self-awareness reflects the significance of recognizing one's feelings and how they affect one's performance. Realizing one's own strengths and weaknesses are attributes of self-assessment. The third competence in the SelfAwareness cluster is self-confidence.

The capability to make sound decisions, despite uncertainties and pressures, the ability to voice unpopular views, and the ability to be decisive are all characteristics of self-confident individuals. Self-Management involves a person's ability to control and regulate his emotions, the ability to stay clam, clear, and focused when things do not go as planned, and the ability for self-motivation and initiative.

The Self-Management cluster of emotional intelligence competencies is the second cluster in the personal competence domain and encompasses six competencies: self-control, trustworthiness, conscientiousness, adaptability, achievement drive, and initiative. Self-control is the ability to manage one's own disruptive and distressing emotions and impulsive feelings by keeping them in check (BOYATZIS, 1982).

Trustworthiness translates into letting others know one's value and principles, intentions and feelings, and acting in ways that are consistent with them (CHERNISS; GOLEMAN, 2001). People who are adaptable are flexible in how they see events, can smoothly handle multiple demands, and are able to adapt their responses and tactics to fit fluid circumstances.

Achievement driven professionals know how to improve their performance by pursuing information to reduce uncertainty and find ways to do better. The final competence in the Self-Management cluster is initiative, which entails taking preventative action to avoid problems before they happen. Social Awareness is the understanding of others' feelings, needs, and concerns which stem from the awareness of one's own feelings.

Social Awareness skills determine how to relate to others, specifically the ability to sense other people's feelings and read the mood of a group; to inspire and build relationships; to work in terms; to listen and to communicate. Sensitively to others is crucial for superior job performance, whenever the focus is on interactions with people. 
INDEPENDENT JOURNAL OF MANAGEMENT \& PRODUCTION (IJM\&P)

http://www.ijmp.jor.br

v. 8, n. 2, April - June 2017

ISSN: 2236-269X

DOI: 10.14807/ijmp.v8i2.550

Three competencies lie within the Social Awareness cluster of the Social Competence domain: empathy, service orientation, and organizational awareness. Empathy is the ability to sense others' feelings and perspectives, and take an active interest in their concerns. The service orientation competence involves anticipating, recognizing, and meeting clients' needs (CHERNISS; GOLEMAN, 2001).

The third competence in the Social Awareness cluster is organizational awareness. Individuals with this ability can understand the political forces at work in an organization, as well as the guiding values and unspoken rules that operate among the people.

Relationship Management, the second cluster in the Social Competence domain, has to do with a person's ability to manage relationships with others and involves the ability to communicate, influence, collaborate, and work with colleagues. The Relationship Management cluster focuses on essential social skills and includes the following competencies: developing others, influence, communication, conflict management, leadership, change catalyst, building bonds, teamwork and collaboration.

Developing others entails sensing what others need in order to develop and reinforcing their abilities. A leader who has mastered the influence competence uses complex strategies like indirect influence and persuasion to build harmony and support with others. Those excelling in the leadership competence are able to articulate and arouse enthusiasm for a shared vision and mission, to step forward as needed, to guide the performance of others while holding them accountable, and to lead by example (CHERNISS; GOLEMAN, 2001).

Those proficient as change catalysts are able to challenge the status quo, to acknowledge the need for change. Leaders must also be able to recognize the need for change, remove barriers, and enlist others in pursuit of new initiatives. The cornerstone of the building bonds competence is networking and nurturing instrumental relationships, all of which are essential for successful change.

\subsection{BPR in Nigerian Banks}

Change management focuses in bringing innovation and improved service delivery in organizations. And to achieve this purpose, banks in Nigeria embraced BPR as a change strategy. For effective BPR and change management, an 
INDEPENDENT JOURNAL OF MANAGEMENT \& PRODUCTION (IJM\&P)

http://www.ijmp.jor.br

v. 8, n. 2, April - June 2017

ISSN: 2236-269X

DOI: 10.14807/ijmp.v8i2.550

organization must be aware of its own choices and also be aware of the emotions of individual employees, and the group, so as to remain competitive.

According to Higgs and Rowland (2001) there is a positive correlation between change competence and effective change management. A major concern in the Nigerian banking industry and in most parts of the world; is on how to improve customer satisfaction, or even exceed their expectations.

Previous studies show that El competencies such as empathy, self awareness, among others are critical in exceeding customer expectations in a service industry (CHERNISS; ADLER, 2000).

In a study of the banking industry in Malaysia, Anonymous (2011) posits that empathy which is the ability to evaluate and recognize emotions, facilitates the managers' role to connect with customers and to fulfill the customers' needs and demands.

BPR focuses on building change competence, and such change competence hinges on the standardization of processes automation, through better deployment of $I C T$, efficient customer service with a focus on turnaround time; friendly ambiance; knowledge sharing and creation; employee motivation; simplification of processes cost effectiveness and efficiency as well as superior internal control systems (PAMELA, et al, 1999; BOGUE, et al, 1996).

Against the backdrop of bank failures in Nigeria in the late 1980s and throughout the 1990s; banks in Nigeria embarked on comprehensive change management through BPR as a measure to reduce the risk and cost of failure by bringing significant improvements in the business process and profitability. The banking industry in Nigeria has witnessed improved service delivery and profitability in recent years through significant transformation and change management processes.

According to Nelson and Orioha (2016) the increased service delivery channels characterized by electronic payment systems with its myriad of products have been beneficial. For example, in 2015, there were 1626 million transactions across all payment channels worth N48.9 trillion processed, which contrasts 113.4 million transactions across all payment channels in 2014, worth N43.9 trillion. 
INDEPENDENT JOURNAL OF MANAGEMENT \& PRODUCTION (IJM\&P)

http://www.ijmp.jor.br

v. 8, n. 2, April - June 2017

ISSN: 2236-269X

DOI: 10.14807/ijmp.v8i2.550

The huge records were facilitated by various channels in electronic automated teller machines, point of sale, among others, brought about by change management in the Nigerian banking industry. The process brought about strategic improvements in many aspects of banking services in Nigeria. For example, First City Monument Bank Ltd (FCMB) has continued to create more value to its growing stakeholders through the electronic banking channels.

The bank believes that effective use of technology and top-most service delivery channels represents the future of banking and the way to go in order to attain the highest levels of customer advocacy and keep pace with evolving consumer demands and market trends. FCMB insists that it has been leading the pack as the largest retail lender in Nigeria, granting over 278,000 loans a year among other giant strides, made easy by change imperatives.

The products and services of the bank are complimented by a team of highly professional and friendly staff, who are always willing to go the extra mile to meet the needs of existing and potential customers. To sustain competitive advantage, the bank upgraded its information technology infrastructure to finacle 10 core banking solution.

This advanced service - oriented architecture is already optimizing the processes, enhancing system capability, performance, scalability and security among others. Change management processes have reduced the problems of over charges and under charges that characterized the banking system in the 1990 s.

As a hangover of the 1990s, in 2015 alone, the CBN investigated over 6000 complaints from banks' customers and compelled banks to refund the sum of over N6.2 billion to affected customers (DEFINONE, 2016).

Banks in Nigeria have often been accused of greed, moral and professional bankruptcy, actions that reflect emotional blindness, and these are issues easily overcome in an emotionally intelligent environment. Business organizations, especially the banking industry in Nigeria, needs to be more efficient and competitive with other banking institutions around the world, thus the need for El and change management as the index of management performance efficiency. 


\subsection{First Bank's Successful Change Management}

By embarking on change through BPR First Bank of Nigeria Plc (1999) sought to drive marketing and relationship management imperatives in tandem with the overall strategy of the bank, and to maximize branch productivity and profitability by ensuring effective performance of branch activities.

The bank believes that competencies like leadership, negotiation, integrity, interpersonal relationships, communication, team building, group problem resolution, among others, are important to establish and manage professional and mutually beneficial relationships with individuals and corporate customers. As a change management strategy, the bank was among the first in Nigeria to provide multiple delivery channels to its branch network so as to bring its services closer to customers.

According to Ajekigbe (2002) First Bank acquired the Finacle banking application software developed by Infosys Technologies of India to meet new operational challenges, and to transform the bank into a one branch bank. He posits that the change management paradigm anchor on the philosophy that subscribe to the core values of hardwork, diligence and an unwavering commitment and dedication to organizational ideals, and employee motivation to achieve higher productivity, through the attraction and retention of the best hands in the industry, using a competitive compensation structure, sustained rejuvenations and constant skills audit and update.

Hammer (1996) believes that reengineering provides a single knowledge point of contact for the customer; and that organization-wide change programmes such as BPR significantly provides guides and directions for consistent, efficient implementation. He suggests that feedback is necessary for a successful change initiative. Without clear feedback, employees often become dissatisfied, and their perceptions of change can be quite different from actual outcomes (BOGUE, et al, 1999).

On the basis of it would seem that at the most theoretical and practical levels, emotional intelligence blends positively with change management in the banking industry as it also emphasizes transparency, accountability among other competencies critical for bank survival. Emotional intelligence is therefore 
DOI: 10.14807/ijmp.v8i2.550

inescapable for the growth of a bank because the banking industry serves as the engine of development in any economy because of its financial intermediation functions that require innovation in the provision of an efficient payment system (UGWUANYI, 2014; UGWUANYI; AMANZE, 2014).

\section{RESEARCH METHODOLOGY}

\subsection{Research Design}

The survey research design was adopted for the study. Surveys are particularly useful in describing the characteristics of a large population or a particular sub group of the population. Surveys refer to an investigation into certain things or events that exist or occur at the time of the research and connected with some problem situation that is felt over a wide area by a large population. (SAUNDERS; THORNHILL, 2009)

\subsection{Participants}

The sample comprised of 483 participants (265 males and 218 females) ranging in age from 21 to $70(M=46$ years; $S D=25)$. The participants were generate from the general population across Nigeria.

\subsection{Materials}

An instrument titled "Emotional Intelligence Change Management Questionnaire (EICMQ)" adapted from the Schutte Self-Report Emotional Intelligence (SSREI) (1998) scale was used for data collection. Previous investigations have found the total scores on the SSREI scale to be acceptably internally consistent with Cronbach's Alpha of about .90. Content and construct validity has been established.

\subsection{Method of data collection}

The instruments for data collection were personally distributed to respondents by the investigator and two research assistants, over a period of four months. The 483 questionnaire copies were retrieved and responses found suitable for the purpose of analysis. 
INDEPENDENT JOURNAL OF MANAGEMENT \& PRODUCTION (IJM\&P)

http://www.ijmp.jor.br

v. 8, n. 2, April - June 2017

ISSN: 2236-269X

DOI: 10.14807/ijmp.v8i2.550

\subsection{Data Analysis}

Data analyses were based on descriptive and X2 techniques, using the Statistical Package for the Social Sciences, for the $\mathrm{X} 2$, and the results presented in tables.

\section{PRESENTATION OF RESULTS}

Table 1: Goleman's (2001) Emotional Intelligence Competencies Clusters

\begin{tabular}{|c|c|c|}
\hline & Self & $\begin{array}{l}\text { Other } \\
\text { (Social Competence) }\end{array}$ \\
\hline Recognition & $\begin{aligned} & \text { Self-Awareness } \\
& \text { - } \text { Emotional } \\
& \text { awareness } \\
& \text { - } \text { Accurate } \\
& \text { assessment } \\
& \text { - } \text { Self-confidence }\end{aligned}$ & $\begin{array}{cl}\text { Social Awareness } \\
\text { - } & \text { Empathy } \\
& \text { Service orientation } \\
\text { - } & \text { Organization } \\
& \text { awareness }\end{array}$ \\
\hline Regulation & $\begin{array}{ll}\text { Self management } \\
\text { - } & \text { Self-control } \\
\text { - } & \text { Trustworthiness } \\
\text { - } & \text { Conscientiousness } \\
\text { - } & \text { Adaptability } \\
\text { - } & \text { Achievement drive } \\
\text { - } & \text { Initiative }\end{array}$ & $\begin{array}{ll}\text { Relationship management } \\
\text { - } \\
\text { - } \text { Influence } \\
\text { - } \text { Communication } \\
\text { - Conflict management } \\
\text { - Leadership } \\
\text { - Change catalyst } \\
\text { - } \text { Building bonds } \\
\text { - Teamwork } \\
\text { collaboration }\end{array}$ \\
\hline
\end{tabular}

The El competencies in table 1 are essential for successful change management.

Table 2: Level of distress in the banking system as at December 1996

\begin{tabular}{|l|r|r|r|r|r|r|}
\hline \multirow{2}{*}{ Parameters } & \multicolumn{3}{|c|}{ December 1995 } & \multicolumn{2}{|c|}{ December 1996 } \\
\cline { 2 - 7 } & $\begin{array}{r}\text { Distressed } \\
\text { Banks } \\
\text { N'000 }\end{array}$ & $\begin{array}{r}\text { Potentially } \\
\text { Distressed } \\
\text { N'000 }\end{array}$ & $\begin{array}{r}\text { Industry } \\
\text { N'000 }\end{array}$ & $\begin{array}{r}\text { Distressed } \\
\text { Bank } \\
\mathbf{N}^{\prime} \mathbf{0 0 0}\end{array}$ & $\begin{array}{r}\text { Potential } \\
\text { Distressed } \\
\mathbf{N}^{\prime} \mathbf{0 0 0}\end{array}$ & $\begin{array}{r}\text { Industry } \\
\text { N'000 }\end{array}$ \\
\hline Number Of Banks & 51 & 9 & 115 & 47 & 3 & 115 \\
\hline Total Assets & 58.168 .385 & $88.667,168$ & $406.961,535$ & $65,132,311$ & $3,906,337$ & $491,469,195$ \\
\hline $\begin{array}{l}\text { Total Risk } \\
\text { Weighted Assets }\end{array}$ & $57,853,920$ & $57,513,301$ & $273,391.4$ & $51,302,649$ & $2,411,615$ & $316,484.2$ \\
\hline Total Deposits & $40,246,569$ & $53,276,884$ & $208,730,351$ & $38,061,592$ & $2,175,857$ & $255,011,875$ \\
\hline $\begin{array}{l}\text { Total Loans, } \\
\text { Advances \& } \\
\text { Leases }\end{array}$ & $51,109,422$ & $39,369,970$ & $175,875,065$ & $50,554,010$ & $1,236,039$ & $213,617,702$ \\
\hline $\begin{array}{l}\text { Insider Loans } \\
\text { Advances \& } \\
\text { Leases }\end{array}$ & $16,117,692$ & 399,432 & $19,083,336$ & $4,651,676$ & 12,605 & $7,780,321$ \\
\hline $\begin{array}{l}\text { Non-Performing } \\
\text { Loans Advances } \\
\text { \& Leases }\end{array}$ & $35,200,461$ & $9,345,372$ & $57,871,794$ & $40,328,307$ & 531,605 & $72,420,970$ \\
\hline $\begin{array}{l}\text { Minimum Capital } \\
\text { Requirement }\end{array}$ & $4,628,314$ & $4,601,064$ & $19,534,766$ & $4,104,212$ & 192,929 & $23,871,509$ \\
\hline $\begin{array}{l}\text { Recapitalization } \\
\text { Requirement }\end{array}$ & $34,012,592$ & $4,193,697$ & $25,325,877$ & $42,360,701$ & 157,136 & $24,662,669$ \\
\hline
\end{tabular}


INDEPENDENT JOURNAL OF MANAGEMENT \& PRODUCTION (IJM\&P)

http://www.ijmp.jor.br

v. 8 , n. 2, April - June 2017

ISSN: 2236-269X

DOI: 10.14807/ijmp.v8i2.550

\begin{tabular}{|l|r|r|r|r|r|r|}
\hline $\begin{array}{l}\text { NDIC's Level of } \\
\text { Risk Exposure }\end{array}$ & $22,304,343$ & 0 & $22,304,343$ & $19,711,933$ & 0 & $19,711,933$ \\
\hline RATIOS: & $\%$ & $\%$ & $\%$ & $\%$ & $\%$ & $\%$ \\
\hline $\begin{array}{l}\text { Capital To Risk } \\
\text { Weighted Assets }\end{array}$ & $(50.79)$ & 0.71 & $(3.60)$ & $(74.57)$ & 1.48 & $(0.27)$ \\
\hline $\begin{array}{l}\text { Non-Performance } \\
\text { Loans \& } \\
\text { Leases/Total } \\
\text { Loans \& Leases }\end{array}$ & 68.67 & 23.74 & 32.91 & 79.77 & 43.01 & 33.90 \\
\hline $\begin{array}{l}\text { Average Liquidity } \\
\text { Ratio }\end{array}$ & $(59.47)$ & 31.14 & 0.49 & $(120.01)$ & 64.69 & $(15.92)$ \\
\hline $\begin{array}{l}\text { Gross Loans \& } \\
\text { Leases/Deposits } \\
\text { Ratio }\end{array}$ & 126.991 & 73.90 & 84.26 & 132.82 & 56.81 & 83.77 \\
\hline $\begin{array}{l}\text { Percentage of } \\
\text { Insured Deposits }\end{array}$ & 55.42 & 0.00 & 50.74 & 77.08 & 0.00 & 11.50 \\
\hline
\end{tabular}

Source: Nigeria Deposit Insurance Corporation (1996) Annual Report \& Statement of Accounts.

Table 2 showed the parameters and extent of distress in the Nigerian banking industry between 1995 and 1996. Capital to risk weighted assets ratio was minus 0.27 percent in 1996, indicating that shareholders' funds were completely eroded.

Table 3: Liquidity Position of Insured Banks

\begin{tabular}{|l|r|r|r|r|r|r|r|r|}
\hline \multirow{2}{*}{ Banks } & \multicolumn{3}{|l|}{$\begin{array}{l}\text { Number of Banks } \\
\end{array}$} & \multicolumn{2}{l|}{$\begin{array}{l}\text { Average Liquidity } \\
\text { Ratio }\end{array}$} & \multicolumn{2}{l|}{$\begin{array}{l}\text { Ratio of Net } \\
\text { Loans \& } \\
\text { Advances to Total } \\
\text { Deposits }\end{array}$} & $\begin{array}{l}\text { Number of Banks } \\
\text { with Average } \\
\text { Liquidity Ratio of } \\
\text { less than 30\% }\end{array}$ \\
\cline { 2 - 9 } & 1995 & 1996 & 1995 & 1996 & 1995 & 1996 & 1995 & 1996 \\
\hline Merchant & 51 & 51 & 29.02 & 12.32 & 64.7 & 80.08 & 18 & 15 \\
\hline Commercial & 64 & 64 & $(22.25)$ & $38.42)$ & 57.6 & 57.4 & 32 & 26 \\
\hline Industry & 115 & 115 & 0.49 & $(15.92)$ & 58.4 & 60.0 & 50 & 41 \\
\hline
\end{tabular}

Table 3 showed the liquidity profile of banks. From the table, the liquidity position of the industry deteriorated as the average liquidity ratio dropped from 0.49 percent in 1995 to minus 15.92 percent in 1996. On the aggregate, both the commercial and merchant bank subsectors could not meet the 30 percent minimum prudential liquidity ratio.

Table 4: Insured Banks Capital Shortfall.

\begin{tabular}{|l|r|r|r|r|r|r|}
\hline \multirow{2}{*}{ Banks } & \multicolumn{2}{|l|}{ Number of Banks } & \multicolumn{2}{l|}{$\begin{array}{l}\text { Adjusted } \\
\text { shareholders' fund } \\
\text { (N'M) }\end{array}$} & \multicolumn{2}{l}{$\begin{array}{l}\text { Capital requirement } \\
\text { (A'M) }\end{array}$} \\
\cline { 2 - 8 } & 1995 & 1996 & 1995 & 1996 & 1995 & 1996 \\
\hline Merchant & 51 & 51 & $(4,869.1)$ & $(1,961.8)$ & $11,672.7)$ & $5,803.1$ \\
\hline Commercial & 64 & 64 & $(3,922.0)$ & 1.171 .0 & $27,162.3$ & 18.859 .6 \\
\hline Industry & 115 & 115 & $(8,791.1)$ & $(791.2)$ & $38,835.0$ & $24,662.7$ \\
\hline
\end{tabular}

Source: NDIC (1996) Annual Report \& Statement of Accounts, pp . 9

Table 4 showed the adjusted shareholders' funds for the industry which decreased from negative N8,791.1m in 1995 to negative N791.2m in 1996. 
INDEPENDENT JOURNAL OF MANAGEMENT \& PRODUCTION (IJM\&P)

http://www.ijmp.jor.br

v. 8 , n. 2, April - June 2017

ISSN: 2236-269X

DOI: 10.14807/ijmp.v8i2.550

Correspondingly, the required capitalization for the size of operation of the banks decreased from N38,835.0m in 1995 to $\mathrm{N} 24,662.7 \mathrm{~m}$ in 1996.

Table 5: Insured Banks' Shareholders' Funds As At December 2010 And 2011

\begin{tabular}{|c|c|c|c|}
\hline S/N & Banks & $\begin{array}{l}\text { Shareholders Funds } \\
\text { (N'Billion) } 2010\end{array}$ & $\begin{array}{l}\text { Shareholders' } \\
\text { fund (N' Billion) } \\
2011\end{array}$ \\
\hline 1 & $\begin{array}{l}\text { Access Bank Nig } \\
\text { Plc. }\end{array}$ & 167.61 & 187.79 \\
\hline 2 & Mainstreet Bank Plc & $(265.27)$ & 35.82 \\
\hline 3 & Keystone Bank PIc & (209.45) & 45.24 \\
\hline 4 & Citibank Nigeria Ltd & 32.17 & 33.70 \\
\hline 5 & Diamond Bank Plc & 110.36 & 91.36 \\
\hline 6 & Ecobank Plc. & 72.28 & 44.99 \\
\hline 7 & Fidelity Bank Plc. & 128.62 & 104.88 \\
\hline 8 & $\begin{array}{l}\text { First Bank of Nig. } \\
\text { Plc. }\end{array}$ & 312.21 & 318.78 \\
\hline 9 & $\begin{array}{l}\text { Fist City Monument } \\
\text { Bank Plc. }\end{array}$ & 127.43 & 130.34 \\
\hline 10 & $\begin{array}{l}\text { Guaranty Trust } \\
\text { Bank Plc }\end{array}$ & 174.49 & 173.99 \\
\hline 11 & Skye Bank Plc & 90.14 & 99.64 \\
\hline 12 & Enterprise Bank Plc. & $(92.40)$ & 11.87 \\
\hline 13 & $\begin{array}{l}\text { Stanbic IBTC Bank } \\
\text { Plc }\end{array}$ & 66.09 & 70.25 \\
\hline 14 & $\begin{array}{l}\text { Standard Chartered } \\
\text { Bank Ltd. }\end{array}$ & 35.92 & 37.42 \\
\hline 15 & Sterling Bank PIc & 21.68 & 27.29 \\
\hline 16 & Union Bank Plc. & $(281.49)$ & 54.25 \\
\hline 17 & $\begin{array}{l}\text { United Bank for } \\
\text { Africa Plc }\end{array}$ & 174.69 & 141.68 \\
\hline 18 & Unity Bank Plc. & 7.69 & 17.99 \\
\hline 19 & Wema Bank Plc. & (3.49) & 11.61 \\
\hline \multirow[t]{2}{*}{20} & Zenith Bank Plc. & 290.80 & 296.04 \\
\hline & Total & 312.36 & $1,934.93$ \\
\hline
\end{tabular}

Source: NDIC (2011) Annual Report and Statement of Accounts.

Table 5 showed positive levels of shareholders' funds between 2010 and 2011 that reflect the impact of successful change management.

Table 6: Insured Banks Ownership Structure As At December, 2011.

\begin{tabular}{|c|c|c|c|c|}
\hline \multirow[t]{2}{*}{ S/N } & \multirow[t]{2}{*}{ Banks } & \multicolumn{3}{|c|}{ OWNERSHIP STRUCTURE (\%) } \\
\hline & & $\begin{array}{l}\text { Shareholders } \\
\text { Funds (N' } \\
\text { Billion) } 2010\end{array}$ & $\begin{array}{l}\text { Shareholders' } \\
\text { fund (N' Billion) } \\
2011\end{array}$ & Foreign \\
\hline 1 & Access Bank Nig Plc. & 1 & 99 & - \\
\hline 2 & Citibank Nigeria Ltd & - & 18.1 & 81.9 \\
\hline 3 & Diamond Bank Plc & - & 100 & \\
\hline 4 & Ecobank Plc. & - & 100 & \\
\hline 5 & Enterprise Bank Plc. & 100 & - & - \\
\hline 6 & Fidelity Bank Plc. & & 100 & \\
\hline 7 & First Bank of Nig. Plc. & - & 100 & - \\
\hline 8 & $\begin{array}{l}\text { Fist City Monument } \\
\text { Bank Plc. }\end{array}$ & & 100 & - \\
\hline 9 & Guaranty Trust Bank Plc & - & 100 & - \\
\hline 10 & Keystone Bank Plc & 100 & - & - \\
\hline
\end{tabular}


INDEPENDENT JOURNAL OF MANAGEMENT \& PRODUCTION (IJM\&P)

http://www.ijmp.jor.br

v. 8, n. 2, April - June 2017

ISSN: 2236-269X

DOI: 10.14807/ijmp.v8i2.550

\begin{tabular}{|l|l|r|r|r|}
\hline 11 & Mainstreet Bank Plc & 100 & & - \\
\hline 12 & $\begin{array}{l}\text { Standard Chartered } \\
\text { Bank Ltd. }\end{array}$ & - & - & 100 \\
\hline 13 & Skye Bank Plc & 1 & 50 & 49 \\
\hline 14 & Stanbic IBTC Bank Plc & - & 47.31 & 52.69 \\
\hline 15 & Sterling Bank Plc & 2.55 & 78.64 & 18.8 \\
\hline 16 & United Bank for Africa & 2.77 & 97.23 & - \\
& Plc & 19 & 21 & 60 \\
\hline 17 & Union Bank Plc. & 35 & 65 & - \\
\hline 18 & Unity Bank Plc. & 10 & 90 & - \\
\hline 19 & Wema Bank Plc. & 2.8 & 97.18 & - \\
\hline 20 & Zenith Bank Plc. & & & \\
\hline
\end{tabular}

Source: NDIC (2011) Annual Report and Statement of Account.

As shown in table 6, there were changes in the ownership structure of banks as a part of the successful change management process in the industry.

Table 7: Liquidity Ratio of Insured Banks as at December, 2010/2011

\begin{tabular}{|l|r|r|}
\hline Items & \multicolumn{2}{|c|}{ Year } \\
\hline & 2010 & 2011 \\
\hline Average liquidity ratio & 51.77 & 65.69 \\
\hline $\begin{array}{l}\text { Loans and advances to deposit } \\
\text { ratio }\end{array}$ & 59.23 & 55.95 \\
\hline $\begin{array}{l}\text { No of Banks with less than the } \\
30 \% \text { minimum liquidity ratio }\end{array}$ & 1 & Nil \\
\hline
\end{tabular}

Source: NDIC (2011) Annual Report and Statement of Account.

As a result of change, and as reflected in table 7, all banks in Nigeria met the 30\% minimum liquidity ratio in 2011, against the situation in 1996.

Table 8: Frequencies

\begin{tabular}{|r|r|r|r|}
\hline & \multicolumn{1}{|l|}{ Observed N } & \multicolumn{1}{l|}{ Expected N } & \multicolumn{1}{l|}{ Residual } \\
\hline 37.00 & 37 & 96.6 & -59.6 \\
\hline 58.00 & 58 & 96.6 & -38.6 \\
\hline 91.00 & 91 & 96.6 & -5.6 \\
\hline 108.00 & 108 & 96.6 & 11.4 \\
\hline 189.00 & 189 & 96.6 & 92.4 \\
\hline Total & 483 & & \\
\hline
\end{tabular}

Table 9: Test Statistics

\begin{tabular}{|l|l|}
\hline & VAR00003 \\
\hline Chi-Square & 142.248 \\
\hline df & 4 \\
\hline Asymp. Sig. & .000 \\
\hline
\end{tabular}

a. 0 cells $(.0 \%)$ have expected frequencies less than 5 . The Minimum expected cell frequency is 96.6 .

\subsection{Discussion}

From the test statistics in table 9, it was observed that the calculated $\mathrm{X} 2$ value of approximately 142 was significantly greater than the table value of 13.28 at 0.01 
INDEPENDENT JOURNAL OF MANAGEMENT \& PRODUCTION (IJM\&P)

http://www.ijmp.jor.br

v. 8, n. 2, April - June 2017

ISSN: 2236-269X

DOI: 10.14807/ijmp.v8i2.550

level of significance and with 4 degrees of freedom. In view of the empirical result, the notion that emotional intelligence has powerful contribution to organizational excellence holds.

This result also agrees with the findings of Cherniss (2000) that salesmen in a USA company were valued primarily for their empathy. The buyers reported that they wanted salesmen who could listen well and really understood what they wanted and what their concerns were.

It equally supports the research of Boyatzis (1999) which found that partners in a multinational consulting company assessed high on emotional intelligence competencies delivered \$1.2million more profit than did other partners. Competition is the driving force behind strategic planning in many organizations. To develop effective strategies business organizations attempt to focus on the areas that would lead towards the achievement of goals.

With strategies come change. To drive change requires competencies involving those special attributes or abilities needed by an organization that gives it a competitive edge. In effect, distinctive competencies relate to the ways that organizations compete. Banks in Nigeria have been going through many structural changes since the 1990s, and 2000s, when the bank failure phenomenon became very disturbing, with the regulatory authorities charting new paths for change in the system.

For example, under a new banking regulatory framework introduced in 2010 by the Central Bank of Nigeria. (CBN), banks are now required to concentrate fully on core banking functions. The new model requires banks to either sell all non-cores banking businesses; including activities such as insurance, asset management and capital market operations.

Based on that, First Bank and four other banks opted for restructuring of their group banking operations into a holding company structure. Other banks are seeking to divest from non-core banking operations. As the largest banking group in Nigeria and easily one of Africa's largest financial services institution, the new First Bank structure eliminates overlapping functions and loopholes and enhances the efficiency of the group structure. 
INDEPENDENT JOURNAL OF MANAGEMENT \& PRODUCTION (IJM\&P)

http://www.ijmp.jor.br

v. 8, n. 2, April - June 2017

ISSN: 2236-269X

DOI: 10.14807/ijmp.v8i2.550

Giving a breakdown of the structure, Onasanya (2012) states that First Bank group consists of 11 subsidiaries operating in various segments of the financial services industry from pension custodian, asset management, investment banking, insurance and microfinance banking, entities.

Besides, the bank also holds investments in other companies, with international presence in the United Kingdom and France, through its subsidiary, First Bank (UK) Ltd, in addition to representative offices in South Africa, China and Abu Dhabi. These structural changes are expected to enhance the productivity of the group, thus creating values for shareholders.

Onasanya (2012) believes that the new structure would enable the group to exploit opportunities for synergies between subsidiaries, while aligning the ownership and operation of the subsidiaries and businesses with current CBN regulatory requirements. He emphases that the new structure would create an operating model that will profitably grow the bank's presence in the market for commercial banking and non-banking financial services in order to achieve the aspiration to be the dominant financial services group in Sub-Sahara Africa.

"The holding company would result in the creation of a corporate centre with responsibility for setting strategic direction, providing group-wide oversight, and ensuring the leveraging of synergies across the group through the constitution of a governing board and committees at the group level to optimally align corporate governance and management roles", he opines.

Also, Diamond Bank Plc since 2010 has been restructuring to improve on performance. According to Achebe (2010) "This improved performance, was as a result of the significant increase in our interest margin and the gains from the initiatives that were implemented to improve operating efficiency and organizational productivity".

He states: "The Bank focuses on its retail, low-cost deposits, thus improving the net interest margin. The risk adjusted returns on retail assets have also been very encouraging. The Bank's ratio of operating expenses to operating income improved from 68.1 percent recorded in 2009 to 62.6 percent in 2010.

The Bank had focused on implementing cost effective business structures and processes which have resulted in more efficient staffing and operating model; all of 
INDEPENDENT JOURNAL OF MANAGEMENT \& PRODUCTION (IJM\&P)

http://www.ijmp.jor.br

v. 8, n. 2, April - June 2017

ISSN: 2236-269X

DOI: 10.14807/ijmp.v8i2.550

which resulted in improved efficiency and productivity". In a study related to the oil and gas industry, but somewhat similar to the present study, Omiyi (2008) states: "The challenge for organizations is to bring to the market a stream of new and improved, added value products and services that enable business to achieve higher margins and the profits to re-invest in the business or provide returns to investors".

He asserts that change requires a supportive culture to thrive. A supportive culture does not happen by accident. It depends on the existence of basic conditions in the organization, such as: knowledge sharing, funding change, implementing new ideas, sound corporate governance culture rewarding people, collaboration with stakeholders, among others.

Omiyi (2008) believes that change is a key business process that enables organizations to compete effectively. Irrespective of sector, innovative organizations realize that to maintain their competitive advantage, they must continually seek to identify, develop and make the best use of all their available resources. He opines that leadership, an enabling organizational culture, and a structured change process are some of the key success factors required to achieve organizational objectives.

To succeed in managing change and innovation, communication with key stakeholders is very necessary. Productivity is a measure of the use of resources, and there is considerable interest in productivity both from an organization standpoint and from a national standpoint. Business organizations want higher productivity because it yields lower costs and helps them to become more competitive.

Countries want higher productivity because it makes their goods and services more attractive, offsets inflationary pressures associated with higher wages, and results in a higher standard of living for their people. Managing successful change requires teamwork, worker involvement, and empowerment, open communication as well as stakeholders' participation. Managing successful change is not once-in-a-life time endeavour. As business circumstances change in major ways, so must processes, designs and structures change (CHASE, et al, 2001; STEVENSON, 2002).

Relationships, partnerships, change management and other factors of emotional intelligence are critical for managing successful change in the Nigerian 
DOI: 10.14807/ijmp.v8i2.550

banking industry. According to Goleman (1995) El ability is necessary to changing value systems as well as rapid technological advancement through the information super high way.

\section{2. $\quad 4.2$ Recommendations}

i. Organizational change process should ensure that employees give and receive proper feedback. This will enable them to provide better services to customers and retain their jobs.

ii. A change process like BPR should focus on automation of critical processes and not employee reduction. This is important so as to enhance effectiveness and loyalty of the workforce.

iii. Banks as custodians of public funds and confidence require a high dose of El factors to survive. In this case, change management in the industry must be transparent.

iv. Integrity is an inescapable factor for banking excellence. Bank promoters should avoid people of dubious character if they must succeed, because people with no integrity are usually both the architects and beneficiaries of bank collapse.

\subsection{Scope for further study}

Further study should examine the relationship between El and corruption to see if the problem of high level corruption could be reduced in the Nigerian banking industry.

\section{CONCLUSION}

Relevant literature points to evidence that emotional intelligence encompasses competencies required for successful change management in the Nigerian banking industry. In 1996, 47 out of 115 banks in Nigeria, were in deep distress, while 3 were potentially distressed bringing to 50 the number of banks adjudged to be technically distressed in 1996 .

Accordingly, the capital to risk weighted assets of banks deteriorated from minus 3.60 percent in 1995 to minus 0.27 percent in 1996. The precarious situation gave course for alarm and made structural change urgent in the Nigeria banking 
INDEPENDENT JOURNAL OF MANAGEMENT \& PRODUCTION (IJM\&P)

http://www.ijmp.jor.br

v. 8, n. 2, April - June 2017

ISSN: 2236-269X

DOI: 10.14807/ijmp.v8i2.550

industry; therefore, almost all the banks embarked upon one type of change or another as a survival strategy.

The evidence in literature that successful banks in Nigeria like First Bank PIc in its change management strategy incidentally relied on emotional intelligence competencies like; integrity, leadership, relationship management, communication, teambuilding, negotiation, among others, supports the hypothesis that El is powerful in successful change management in the Nigerian banking industry.

For example, building on successful change management, First Bank Plc. posted the highest shareholders' funds of N318bn among all the 20 banks in Nigeria in 2011. From a deep distressed position between 1995 and 1996, characterized by weak ownership structure, capital base, liquidity, performing loan assets ratio, the Nigerian banking industry became strengthened after various change management processes.

For example, from a minus 15.92 percent liquidity ratio in 1996, the average liquidity ratio of banks in Nigeria rose sharply to 65.69 percent in 2011, and with all banks achieving the 30 percent prescribed minimum liquidity ratio, against a zero status in 1996. Also the shareholders' funds of some mismanaged banks that were changed to Mainstreet Bank Plc., Keystone Bank Plc., were minus N265billion, and N209billion, respectively in 2010.

But after the intervention of the $\mathrm{CBN}$ and change management processes, their shareholders' funds rose to N35billion, and N45billion, respectively in 2011. Based on theoretical and statistical analyses this study found a strong positive relationship between emotional intelligence and successful change management in the Nigerian banking industry.

As a contribution this result supports the works of Boyatz's, (1982, 1994, 1996) Higgs and Roland (2001) and Goleman (1995, 1998, 2001) among others, to state that emotional intelligence is critical for successful change management. This is the interest of the study.

\section{REFERENCES}

ACHEBE, N. (2011) Diamond Bank Records N9.5bn Profit, Pays 15k Dividend. The Nation, v. 05, n. 1746, p.59. 
AGBATO, J. O. (1990) Managing Organizational Change and Conflict In:

AGBATO, J. O. (ed.) The Nature of Management, Lagos Abiola Bookshops Limited, p. $145-154$.

AGU, C. N. (2000) Fundamentals of Small Business Management and Entrepreneurship Development. Owerri 1 - 0 Publishers.

AJEKIGBE, J. M. (2002) Managing Director's Review. First Bank of Nigeria Plc (2001/2002) Annual Report \& Accounts, Lagos, p. 19-23.

ANONYMOUS (2011) The Impact of Emotional Intelligence Towards the Effectiveness of Delegation: A Study in Banking Industry in Malaysia. International Journal of Business and Social Studies, v. 2, n. 18, p. 93-99.

BARLETT, C. A.; GHOASHAL, S. (1995) Rebuilding Behavioural Context: Turn Process Reengineering into People Rejuvenation. Sloan Management Review, Fall, p. 11-23.

BOGUE, E. M.; SCHWARTZ, M. J.; WATSON, S. L. (1996) The Effects of Reengineering: Fad or Competitive Factor. Journal of Healthcare Management, $v$. 44, n. 6, p. 456.

BOYATZIS, R. E. (1982) The Competent Manager: A Model for Effective Performance New York, John Wiley \& Sons.

BOYATZIS, R. E. (1994), Stimulating Self-Directed Change: Managerial Assessment and Development, Journal of Management Education, v. 18, n. 3, p. 304-323.

BOYATZIS, R. E. (1996) Consequences and Rejuvenation of Competent Based Human Resource and Organizational Development. Research in Organizational change and Development, v. 9, p. 101-122, Greenwich, CN: JAl Press.

BOYATZIS, R. E. (1999), Self-Directed Change and Learning as a Necessary Meta-Competency for Success and Effectiveness in the $21^{\text {st }}$ Century. Keys to Employee Success in the Coming Decades, Westport, CN: Greenwood Publishing, p. 15-32.

CHASE, R. B.; AQUILANO, N. J.; JACOBS, F. R. (2001) Operations Management for Competitive Advantage $9^{\text {th }}$ Edition, USA, McGraw-Hill, Irwin.

CHERNISS, C. (2000) Emotional Intelligence: What it is and why it matters. Paper Presented at the Annual Meeting of the Society for Industry and Organizational Psychology, New Orleans, LA, April 15.

CHERNISS, C.; ADLER, M. (2000) Promoting Emotional Intelligence in Organizations, August, 2000, ASTD.

CHERNISS, C.; GOLEMAN, D. (2001) The Emotionally Intelligent Workplace. San Francis CA, Jossey-Bass.

COOPER, R. (1997) Applying Emotional Intelligence in the Workplace. Training \& Development, v. 51, n. 12, p. 31-38.

DEFINONE, J. (2016) Excess and Unauthorized Charges, by Banks. The Guardian, V. 32, n. 13578, p. 16.

DAVENPORT, T. H. (1993) Process Innovation: Reengineering Work Through Informational Technology. Boston, Harvard Business School Press. 
INDEPENDENT JOURNAL OF MANAGEMENT \& PRODUCTION (IJM\&P)

http://www.ijmp.jor.br

v. 8, n. 2, April - June 2017

ISSN: 2236-269X

DOI: 10.14807/ijmp.v8i2.550

DRUCKER, P. F. (1998) Innovations and Entrepreneurship, Oxford. Butterworth, Heinemann.

DRUCKER, P. F. (1999) Management: Tasks, Responsibilities, Practices. Oxford Butterworth, Heinemann.

FIRST BANK OF NIGERIA PLC (1999) Job Descriptions - Reengineered

Branches, Lagos. Changing-to-win - The First Bank Century Project.

GOLEMAN, D. (2001) Emotional Intelligence Competencies Clusters. New York, Bantam Books.

GOLEMAN, D. (1995) Emotional Intelligence, New York, Bantam Books.

GOLEMAN, D. (1998) Working with Emotional Intelligence, New York, Bantam Books.

GOLEMAN, D.; Boyatzis, R. E.; McKee, A. (2000) Primal Leadership, Realizing the Power of Emotional Intelligence, New York, Bantam Books.

GUEST, R. H. (1964) Organizational Change. The Effect of Successful Leadership. Homewood, 121, Dorsey Press and Richard, D, Irwin, Inc.

HAMMER, M. (1990) Reengineering Work: Don't Automate, Obliterate. Harvard Business Review, v. 90, n. 4, p. 104-12.

HAMMER, M. (1996) Beyond Reengineering. New York, Harper Collins.

HAMMER, M.; Champy, J. (1993) Reengineering the Corporation: A manifesto for Business Revolution New York: Harper Business.

HAMMER, M.; Staton, S. (1999) How Process Enterprises Really Work. Harvard Business Review, v. 99, n. 6, p. 108-18.

HIGGS, M. J.; ROWLAND, D. (2001) Building Change Leadership Capability: the quest for Change Competence. Journal of Change Management, v. 1, n. 2, p. 31116.

MARGRETTA, J. (1998) The Power of Virtual Integration: An Interview with Dell Computer's Michael Dell. Harvard Business Review, March-April, p. 73-84.

MORRELL, K. M.; LOAN-CLARK, J.; WILKINSON, A. J. (2004) Organizational Change and Employee Turnover. Personnel Review, v. 32, n. 2, p. 161-173.

MUO, I. K. (1999) Leadership Imperatives for Successful Change In: MUO, I. K. (ed.) The Nature, Scope \& Challenges of management Lagos. Impressed Publishers. p: $123-128$.

NELSON, C.; ORIOHA, L. (2016) Deepening, inclusion with electronic banking offerings. The Guardian, v. 32, n. 13578, p. 26.

NIGERIA DEPOSIT INSURANCE CORPORATION (1996) Annual Report and Statement of Accounts, Abuja.

NIGERIA DEPOSIT INSURANCE CORPORATION (2011) Annual Report and Statement of Accounts, Abuja.

OLASINDE, T. (2016) Don Advocates Professionalism in Banking Sector. The Guardian, v. 32, n. 13647, p. 29. 
OMIYI, B. (2008) Managing Change and Innovation in the Oil and Gas Industry. Managing in Nigeria, v. 44, n. 3, p. 7-13.

ONASANYA, B. (2012) First Bank, New Structure Greater Values. The Nation, v. 7, n. 2236, p. 33

OVIA, J.; (2003) Payment System and Financial Innovation. Lagos. The Nigerian Banker.

PAMELA, R, J.; INDVIK, J. (1999) Organizational benefits of having emotionally intelligent managers and employees. Journal of Work Place Learning, v. 11, n. 3, p. 84-88.

POVEY, B. (1996) Continuous Business Improvement. London, McGraw-Hill Companies.

ROACH, S. (1998) In Search of Productivity, Harvard Business Review, Sept-Oct, p.153

ROHLEDER, T, R.; SILVER, E. A. (1997) A Tutorial on Business Process Improvement. Journal of Operations Management, v. 15, n. 2, p. 139-54.

SALOVEY, P.; MAYER, J. D. (1990) Emotional Intelligence, New York, Baywood Publishing Co., Inc.

SAUNDERS, M.; LEWIS, P.; THORNHILL, A. (2009) Research Methods for Business Students London, Pixoran Publication.

SCHUTTE, N. S.; MALOUFF, J. M.; HAN, L. E.; HAGGERTY, D. J.; COOPER, J. T.; GOLDEN, C.; DOMHEIM I. (1998) Development and Validation of a Measure of Emotional Intelligence. Personality and Individual Differences, v. 25, n. 2, p. 167177, doi:10.1016/S0191-8869(98)00001-4

STALK, G.; EVANS, P.; SHULMAN, L. E. (1992) Competing on Capabilities: The New Rules of Corporate Strategy. Harvard Business Review, March-April, p. 5769.

STEVENSON, W. J. (2002) Operations Management. $7^{\text {th }}$ edition. USA, McGrawHill, Irwin.

UGOANI, J. N. N. (2013) Effect of Emotional Intelligence on Bank Success:

Published (2010) PhD Dissertation; Germany, Lambert Academic Publishing.

UGWUANYI, G. O. (2014) Banking Distress and the Erosion of Public Confidence in the Nigerian Banking System. European Journal of Business and Management, v. 6, n. 9.

UGWUANYI, G. O.; AMANZE, P. G. (2014) Banking Sector Reform: An Approach to Restoring Public Confidence on the Nigerian Banking Industry. Research Journal of Finance and Accounting, v. 5, n. 6. 